\title{
Environmental Reform, Negative Duties, and Petrocrats: A Strategic Green Energy Argument
}

\author{
Shmuel Nili, Yale University
}

This article constructs an argument for the development of green energy that can appeal to Americans moderately skeptical of climate change. Accepting-arguendo and in a qualified way-key empirical and normative assumptions of American environmental skeptics, I make two main moves. First, while environmentalists often justify the development of green energy through references to future generations, I try to show that they need a present-oriented argument focused on negative duties to respect rights in order to justify prioritizing the development of green energy to environmental skeptics in the United States. Second, I construct such an argument, calling on affluent democracies to develop green energy in order to be able to stop their complicity, through oil trade, in petrocrats' violation of their peoples' property rights. I anticipate multiple objections, including the objection that stopping trade with petrocrats will not lead to green energy as a replacement.

$\mathrm{C}$ onsidered schematically, one can suggest three main ways in which political philosophers might contribute to democratic discussions of public policy. First, when important moral intuitions about a given public issue seem to conflict, philosophers can try to provide "guidance where guidance is needed" (Rawls 1999, 18) by constructing theories that adjudicate among these intuitions or render them coherent, identifying the resulting policy principles. Second, philosophers can aid democratic deliberation by assigning moral priorities among policies that are all agreed to be required by justice. Third, even where the moral justification of an important public policy seems overdetermined, and its priority clear, there might sometimes be legitimate opponents who reject both the prevalent moral arguments for the policy and its urgency. In this context, the most distinctive contribution open to philosophers who support the disputed policy is to reconstruct the opponents' moral claims in their strongest form and show that even on these terms, the policy in question is in fact justified and urgent.

My aim here is to make this last, "strategic" type of philosophical contribution. I seek to do so, specifically, with regard to a key public policy demand of the environmental move- ment: to push forward, through all governmental means possible, the development of clean renewable energy to replace affluent democracies' reliance on oil. This is not the only energy policy demand of the environmental movement (green alternatives to coal are at least equally important). But insofar as oil "still accounts for roughly a third of the primary energy supply worldwide, and transportation systems everywhere remain overwhelmingly dependent on petroleum-based fuels" (Florini 2012, 293-94), the development of green alternatives to oil would clearly constitute a significant environmental achievement. In turn, the most important critics of policies pursuing such alternatives are environmental skeptics in the United States. I will accordingly accept - though solely for the sake of discussion and in a qualified way-key empirical and normative assumptions associated with American skepticism regarding climate change. From this starting point, I will make two main moves. First, while environmentalists often justify the development of green energy through moral claims regarding future generations, I will try to show that they need a present-oriented strategy focused on negative duties to respect rights in order to justify prioritizing the development of green energy to environmental skeptics in the United States. Second, accordingly, I will construct an ar-

Shmuel Nili (Shmuel.nili@yale.edu), Political Science, Yale University.

The Journal of Politics, volume 77, number 4. Published online August 11, 2015. http://dx.doi.org/10.1086/682580

(C) 2015 by the Southern Political Science Association. All rights reserved. 0022-3816/2015/7704-0003\$10.00 
gument for the development of green energy that is based on duties to respect the property rights of existing persons. The heart of this argument, to anticipate, will be that affluent democracies must develop green energy in order to be able to stop their complicity, through oil trade, in petrocrats' violation of their peoples' property rights.

I elaborate this strategic argument as follows. I begin by providing further background on the kind of argument that I wish to construct and by explaining (among other things) why I put aside environmentalist claims regarding the threat that climate change poses to existing generations (see the first section, "Environmental Philosophy and Political Engagement"). I proceed to outline the skeptical position within whose terms the argument will run, and lay out a philosophical version of the skeptical attack on green appeals to future generations (in the second section, "The Skeptic"). I then present the strategic argument for the development of green energy, based on democracies' duty to prohibit their corporations from purchasing oil controlled by dictators (in the third section, "An Alternative Argument for Green Energy"). Finally, I anticipate objections, including the objection that stopping trade with petrocrats will not lead to green energy as a replacement (in the fourth section, "From Dictatorial Oil to Green Energy?”).

\section{ENVIRONMENTAL PHILOSOPHY AND POLITICAL ENGAGEMENT}

The arguments to follow assume that philosophical discussions of environmental public policy should be informed by concrete challenges facing environmentalism as a political movement. Such an approach aligns with the way at least some scholars conceive of the purpose of environmental political theory. "Environmental philosophy," Avner de-Shalit, for instance, emphasizes, "is not simply an armchair exercise, nor is it a discipline of purely academic interest. The goal of environmental philosophers-interestingly, many of them are also activists-is to influence policies and change the world we live in" (de-Shalit 2000, 3). Environmental theorists, David Schlosberg recently insisted in similar spirit, must connect their understanding of "environmental or climate justice" to "the actual demands of social movements that use the idea as an organising theme or identity" (Schlosberg 2013, 50). An argument that can push even environmental skeptics to endorse policies at the heart of the environmentalist agenda comports well with this practical orientation.

In turn, no practical discussion of environmental skepticism can ignore the distinct significance of the American context. The United States is of special importance to the environmentalist cause due to its geopolitical clout, the sheer impact of its policies on the global environment, and its reluctance, in comparison to many other liberal democracies, to pursue environment-friendly policies when these conflict with other societal goals. This state of affairs is supported by the world's most aggressive anti-environmentalist campaigns, most of which are tied to conservative political organizations, including numerous think tanks (Jacques, Dunlap, and Freeman 2008; Oreskes and Conway 2010) and, to a growing degree, the Republican Party (Dunlap, Xiao, and McCright 2001; Layzer 2012). These campaigns, in turn, routinely appeal to normative ideas that are at the heart of American political culture when seeking public support for their preferred policies. An argument that consciously begins from at least some of these ideas - that engages directly with key elements of the public philosophy of American societyis therefore especially well suited to confronting environmental skeptics (as much as possible) on their own terms.

In order to engage American anti-environmentalism in the most fruitful way, I will construct here what I take to be the strongest possible account of its positions. This account will be represented in our discussion by the imaginary figure of "the skeptic." Though the figure is fictional, it is not meant to be a caricature. Four features are supposed to guarantee this. First, our skeptic will be equipped with a wide range of arguments, extending beyond the specific domain of environmental issues to include broader arguments familiar in American political thought and discourse (especially from the right wing of American politics). Second, these arguments will be presented in a way that will make them as internally coherent as possible. Third, in imagining the skeptic response to certain green claims, my focus will be on the strongest and most coherent arguments that right-wing American skeptics can make that will have some intuitive moral force rather than on the arguments that rightwing American skeptics actually make.

Fourth, our skeptic will be moderate, in the following sense: he will accept that environmental degradation poses genuine threats and will accordingly recognize that fossil fuels cannot be relied upon indefinitely. But our skeptic will nonetheless be much more leisurely about the pace of energy reform than environmentalists are. The assumption with which our skeptic will begin is that at some point a shift to green energy will be necessary, but that this point is much further down the line than environmentalists make it seemeven if, as opposed to what radical skeptics argue, such a point does exist. This is because, while our skeptic affirms that global warming is a genuine concern that should be confronted in the long run, he denies that present generations face grave (let alone existential) risks due to global warming. Our skeptic thus agrees with Bjørn Lomborg that "global 
warming is real-it is man-made and it is an important problem. But it is not the end of the world."

My attempt to work within these moderately skeptical terms is bound to trigger several objections. Since these objections bear in fundamental ways on the entire argument, I want to anticipate them already at this early stage. First, some environmentalists might insist that any kind of skepticism regarding the threat posed by climate change, including skepticism as to the threat that climate change poses to present generations, must simply be rejected out of hand as incompatible with scientific evidence. Therefore, any approach that seeks to accommodate environmental skepticism in any way is fundamentally misconceived from the outset.

One response to this objection is the following. Since environmentalists themselves emphasize how urgent it is to prioritize the development of green energy, a new argument that might help win support for such priority is significant, even if some of those that the argument might convince hold empirical assumptions regarding climate change that many environmentalists consider false. If there is potential convergence on measures that environmentalists themselves declare to be crucially time sensitive, this should matter independently of enduring disagreements among supporters of these measures. It hardly seems sensible, for example, to say that I should refuse to enlist your support in managing what I myself declare is a potentially lethal fire, until I make sure that you support the effort because you agree with me on our precise reasons for fighting the fire. The same point applies here. There is value to environmentalist coalition building that reaches practical agreement on the right course of action, even if some parties accept this agreement motivated by what environmentalists deem to be the wrong reasons. ${ }^{2}$

Another response to the objection is that it portrays my argument as more exclusionary than it actually is. I do not mean to suggest that environmentalists need to forget the facts of climate change, or forget their broader value system, when making policy arguments in the American context. Nothing in the argument I will present here goes against environmentalists continuing to emphasize the scientific consensus on the facts of climate change, for example, or even, more specifically, emphasizing the threat that climate change

1. Quote from Sophie Elmhirst, “The NS Interview: Bjørn Lomborg," New Statesman, September 24, 2010, http://www.newstatesman.com/environment /2010/09/interview-gay-climate.

2. I am grateful to Simon Caney for this formulation. A remarkable example of such environmentalist coalition building is the Green Tea Party, a coalition for solar energy between environmentalists and Tea Party members who see solar energy as a response to state energy monopolies. See Carolyn Kormann, "Greening the Tea Party," New Yorker, February 17, 2015, at http:// www.newyorker.com/tech/elements/green-tea-party-solar. poses to present generations. What I am suggesting is an additional argument, which might generate support for green energy policies among some who have been at least somewhat unmoved by environmentalists' factual claims.

My last response to the objection is similarly practical. It is important to bear in mind that, even after decades of environmentalists emphasizing the scientific consensus regarding the facts of climate change, a sizeable portion of US public opinion-albeit to varying degrees-believes that climate change is less urgent of a concern than environmentalists argue (Leiserowitz and Smith 2012). Exactly because time is of the essence, I am suggesting that environmentalists take seriously this enduring state of US public opinion not only by trying to alter it but also by trying to show that even premises closer to those of their opponents can lead to the policies that environmentalists themselves deem urgent.

Now, some environmentalists might grant that there could in principle be value in addressing American environmental skeptics on their own terms but insist that there is nonetheless a serious concern about the kind of argument I wish to make. The concern is that even moderately skeptical premises will never suffice to convince radical anti-environmentalists who completely deny the reality of climate change and who are the real opponents of the environmentalist movement, especially in the United States.

This objection would only work if US public opinion on environmental issues was far more binary than it actually is. It is simply not the case that there exists only a straightforward dichotomy with regard to environmental issues, featuring environmentalists on one side and radical climate change deniers on the other. It is far more plausible to understand US public opinion on the environment as a scalar matter-as featuring many different points on a very wide spectrum. Radical denial of any large-scale environmental threats is merely one point on this spectrum, even if such radicals are particularly vocal (partly for the reasons noted above). Furthermore, while environmentalists may not have any possibility of convincing radical skeptics, and may just have to hope to outvote them, one useful way to try to achieve this is to devise new arguments that can appeal to moderate skeptics: to those who, while not committing themselves to extreme views, are attentive to extreme skeptics, and empathize with (at least some of) the normative claims associated with extreme skeptics.

In order to provide some empirical backing to these claims, and in order to see that moderate environmental skepticism is far from uncommon, it will be helpful to consider the most comprehensive project examining US public opinion regarding climate change. This is the "Six Americas" project, which distinguishes among six different segments of Americans 
according to their views on environmental threats (labeled "Alarmed," "Concerned," "Cautious," "Disengaged," "Doubtful," and, only at the very anti-environmentalist extreme, "Dismissive"). According to the project's latest report, detailing survey findings from October 2014, the largest segment, which includes (at 31\%) almost a third of American adults, is that of the Concerned, who "tend to view global warming as a threat to other nations and future generations, but not as a personal threat or a threat to their community" (RoserRenouf et al. 2015, 7; italics mine). The second-largest segment $(23 \%)$ is that of the Cautious, who are "less worried than the Concerned," and who think of global warming as a "distant threat" (Roser-Renouf et al. 2015, 7). ${ }^{3}$ Moreover, while the Concerned and the Cautious "range in certainty about the reality and dangers of climate change, they are similarly inclined to believe it is a real threat that should be addressed" (Roser-Renouf et al. 2015, 7; italics mine). If we combine the two groups, then we find that $54 \%$ of American adults hold positions on climate change that at least roughly correspond to those of the "moderate skeptic" I have sketched. ${ }^{4}$ Therefore, even if the figure of the moderate skeptic is not meant to be a precise reflection of current public opinion in the United States, it would be a mistake to dismiss it as entirely detached from any actual public sentiment.

There is, however, an important sense in which I will indeed be keeping my argument detached from political realities. Despite its pragmatic, real-world spirit, the position I will advance here will have a distinctly philosophical form. Thus, for example, as will quickly become obvious, I will give a central place to certain philosophical ideas (among other things, concerning the nature of rights and duties, and the moral status of future persons) that are far more abstract and complex than those that typically dominate real-life political debates. This gap between political philosophy and political practice is likely to trigger a final fundamental worry about my approach: that, for all of its practical framing, it is far too academic to resonate in actual political discourse.

To prevent misunderstanding, let me stress that I do not entertain the illusion that the philosophical claims I

3. The Concerned and the Cautious are significantly larger than the group most anxious about environmental threats (the Alarmed, who amount to $13 \%$ of the respondents). But the Concerned and the Cautious are also significantly larger than the group of the most radical environmental skeptics (the Dismissive, who, like the Alarmed, account for 13\%, and who are "very certain that global warming is not occurring").

4. The same two groups also accounted for $54 \%$ in the "Six Americas" survey of September 2012 (when the Concerned accounted for 29\%, and the Cautious for 25\%). See Leiserowitz et al. $(2013,5)$. More generally, in 10 of the 11 national surveys that have been tracking the Six Americas since 2008, the Concerned have been the largest segment of the six. See Roser-Renouf et al. (2015, 7). will develop here can enter actual political debates in anything like an easy-let alone immediate-manner. But I nonetheless believe that there is value in asking how political debates would look if the proponents of the different value systems that actually clash in the public sphere made more room for the kind of foundational normative thinking and coherent argumentation that political philosophers seek.

Furthermore, it is also my belief that insofar as academics can and should strive to make distinctive contributions toward addressing actual societal issues, much of this contribution lies precisely in constructing tighter and more coherent arguments than the political arena often displays. This point, it is worth noting, obtains not only for philosophers. It also obtains for legal scholars, who seek, for example, to provide theoretical accounts of the law's internal coherence, even while recognizing the degree to which real-world law is shaped by "messy" politics. And the same point similarly obtains for social scientists, who often construct complex theoretical models, both explanatory and prescriptive, notwithstanding their knowledge that real-world political decisions and situations inevitably deviate from their models in numerous ways. If academics were to forsake the pursuit of theoretical coherence or rigor because political practice is often too incoherent or simplistic, this would mean giving up on any added value that academics can bring to public debate. It would also require assuming that the quality of public debates can never improve. But this, it seems to me, is an undemocratic assumption that all academics ought to avoid.

With these points in mind, we can turn to examine in greater detail the moderately skeptical position within whose terms my argument will run. I will start with a list of its basic elements and then show how they can be tied together as a coherent whole to oppose familiar environmentalist arguments for the development of green energy.

\section{"THE SKEPTIC" \\ Foundations of the skeptic position in American political culture}

I will attribute to our moderate skeptic a cluster of ideas prominent in American political culture. Perhaps the most foundational of these ideas is the primacy of rights, which has three main implications. First, agents' rights are normally assumed to trump utilitarian calculations of other agents' welfare. Second, the emphasis of public policy and legislation is on negative duties not to violate the immunities that rights provide. Third, related, the primary (if not only) kind of moral duties that public policy and legislation should be based on are duties that correspond to rights. This means, for one thing, that positive duties to help, as distinct from negative duties to refrain from violating rights, are rel- 
egated to a distinctly secondary role: "The grain of the AngloAmerican moral and legal tradition," as Thomas Pogge writes, denies "that persons have duties to protect and aid other persons in distress" (Pogge 1989, 34). While there may be a governmental duty to aid individuals whose very survival is at stake, any broader positive duties to aid are often seen as only supererogatory, and their enforcement through law is cast as illegitimate, among other things, since such enforcement itself violates agents' rights. ${ }^{5}$ Furthermore, public policy and law should focus on ensuring that agents respect the rights of others. Moral demands that arise from supposed duties that agents have toward themselves-to cultivate themselves, to develop certain sensibilities or virtuescannot be incorporated into law without triggering firmly entrenched fears of paternalism, as well as accusations of violating the state's moral duty not to endorse specific conceptions of what amounts to a good life. ${ }^{6}$

Alongside these claims, American political culture is dominated by Lockean ideas concerning property, prosperity, and innovation. ${ }^{7}$ Property rights have a pivotal place in the list of rights that public law and policy should protect. In turn, agents' freedom to exercise their property rights is seen as the key driver of society's economic prosperity, while government regulation is deemed as almost always a threat to both this freedom and prosperity. Because of its significance, attention is constantly given to any (perceived or real) tradeoffs between economic prosperity and other public goods: noneconomic public goods that are seen as undermining economic growth are unlikely to gain policy precedence. Finally, American public culture emphasizes human capacity for transforming nature into prosperity through skill, labor, and innovation. This emphasis generates a particularly pronounced optimism regarding the ability of human technology to overcome natural predicaments.

Let us now see how the ideas of the last two paragraphs, combined with the moderate empirical skepticism noted above, translate into a rejection of the environmentalist de-

5. This point finds expression even in American popular comedy. The final episode of the famous Seinfeld sitcom, for instance, features Seinfeld's lawyer stunned to hear about a new "Good Samaritan law," responding: "Good Samaritan Law? Never heard of it. You don't have to help anybody. That's what this country's all about." See http://www.seinfeldscripts.com /TheFinale.htm.

6. It is worth emphasizing that this is not a fringe intuition characterizing only extreme libertarian views. To give only one well-known example from American philosophy: Rawls's famous insistence on the "inviolability" of the person who spends his days "counting the blades of grass" (Rawls 1999, 3, 379) reflects a rejection of paternalism that is just as trenchant as the one expressed by Rawls's libertarian critics.

7. For a contemporary statement of these ideas, see Zuckert (2002). mand to make the development of green energy a public policy priority.

\section{The skeptical critique}

Because our moderate skeptic rejects empirical green arguments referring to environmental calamities facing present generations, I focus on future-oriented environmentalist arguments and on how our skeptic might respond to such arguments. What moral arguments can our skeptic make in response to moral appeals to future generations? The skeptic can start by attacking all future-oriented arguments that appeal to moral considerations other than those associated with negative duties not to violate rights. Here we can imagine the skeptic saying the following: "Environmentalists can talk about intuitive sensibilities towards future generations, and can chastise contemporary-centric arrogance; they can contend that existing lives will be more fulfilling if future generations are kept in mind, and they can seek to extend the cognitive and emotional time-horizon of individual lives. But a public policy based on such arguments would be paternalistic (because it would impose policies on citizens 'for their own good') and would violate the state's duty to remain neutral among different conceptions of the good life (by imposing on some citizens others' conceptions of what gives value to life). Therefore, all of these arguments can at most serve as guides for the behavior of individuals or voluntary civil society groups. As long as they do not convincingly appeal to negative duties not to harm future generations, none of these arguments can be used to justify public policies that shift resources to future generations at the expense of current generations."

Having narrowed the discussion to negative duties toward future generations, the skeptic might highlight the difficulties in establishing that present generations are violating such negative duties-are harming future generations in morally significant ways. Suppose for the moment that the skeptic accepts a comparative notion of "harm," according to which setting back agents' important interests counts as illegitimately harming them. Under this notion, the skeptic can present two arguments against the environmentalist charge of "harming" future generations.

First, the skeptic will argue that present generations suffer from serious epistemic problems regarding the interests of future generations. This is not only because present generations cannot know what the exact interests of future generations will be. It is also because present generations cannot know what trade-offs between what interests future generations will be forced to make. Since it is extremely hard to know what future generations may have to give up for the sake of environmental goals, it is difficult to say with any 
confidence that nonenvironmental policies will set back their overall interest. Present generations cannot even fully know (or conceptualize) the parameters or dimensions of these tradeoffs. "Would we expect the generations of the eighteenth century," the skeptic would say, "to make sense of the dilemmas of the twentieth century between development and conservation? And if not, why should we be confident of our ability to make sense of the dilemmas and trade-offs of (say) the twenty-third century?"

Second, the skeptic will continue, even if we assume that the shape of future trade-offs can be sufficiently clear to present generations, this still does not mean that present generations have a duty to adopt policies that favor the environmental side of the trade-off, nor does this mean that present generations will be harming future generations by failing to make the environmental choices for them. After all, it might very well be that future generations will themselves prefer the nonenvironmental side of these trade-offs, in much the same way, for example, that many developing countries are currently prioritizing economic growth over environmental goals.

The skeptic can make both of these arguments even if he accepts the assumption that setting back others' important interests necessarily means violating a negative duty not to harm them. But the skeptic is in fact likely to reject even this assumption. He might say the following: "We do not in fact think that setting back people's important interests necessarily means violating a negative duty not to harm them. For instance, Jane might make Jack significantly worse off by driving him out of business through legitimate competition, but that in itself does not necessarily mean that Jane illegitimately harmed Jack. Similarly, even if it could somehow be established that present generations are setting back important interests of future generations by avoiding more environment-friendly policies, this does not by itself mean that present generations are violating a negative duty not to harm future generations."

Arguably the only thing that would convince the skeptic that present generations are violating negative duties toward future generations is an argument showing that the former are violating the latter's rights in some reasonably clear way. But here all that the skeptic has to do is to point out the various works in which philosophers have argued that even if present generations have duties toward future generations, these duties cannot stem from any rights of future generations. Indeed, despite valiant efforts from multiple directions, it remains difficult to defeat the claim that future persons are merely "possible persons" (Macklin 1981, 152) who cannot have any rights in the present. Even if one concedes that the existence of future persons is "virtually certain" (Feinberg 1981, 147), it is hard to entirely defeat the intuition-to which the skeptic is bound to cling as forcefully as possible-that "when and only when a person will come into existence, she will have rights" (Gosseries 2008, 456).

The difficulties involved in ascribing rights to future persons have triggered the rise of an explicitly "concessional view" (Elliot 1989, 162), seeking to argue for future-based duties even without an appeal to any supposed present rights of future persons. But from the perspective of our skeptic, to argue for duties toward future persons that amount to "more than they have a right to" (Meyer 1997) is already to argue for the kind of duties that can at most guide only supererogatory private action, not public policy.

If environmentalists wish to retain their focus on the needs of future generations, but also to argue strategically, from premises closer to those of their critics, then it seems that at this point there is only one more claim to which environmentalists might appeal. Environmentalists might contend that if present generations do not pursue green policies-chief among them the development of clean renewable energythis will threaten the very survival of future generations. Such a claim could invoke a Lockean proviso stipulating a right to basic subsistence, or even simply a very minimal positive duty to help others survive.

The chief problem with an appeal to the very survival of future generations, however, is that it invites even the moderate critic to accuse environmentalists of excessive pessimism. Our moderate skeptic can be expected to say something like the following: "To be sure, we will need to do so something about the environment eventually. But to prophesize that environmental degradation will very soon threaten human survival on a massive scale is nonetheless too apocalyptic. Even if such a claim could be proven (which is doubtful) it in effect holds technology constant, and thus-cruciallyignores human capacity for innovation. Doomsday predictions regarding humanity's inability to tend to its basic needs are nothing new, and these predications have been repeatedly shown wrong by technological progress."

The skeptic will not find it too hard to come up with evocative examples, either. For instance, it is all too convenient to associate environmentalist alarmism about future survival with past Malthusian fears that have been vastlyand with hindsight, easily_disproved by technology. In 1798, the skeptic will remind his opponents, Thomas Malthus declared, "The power of population is indefinitely greater than the power in the earth to produce subsistence for man" (Malthus 2008, 13). Yet only 150 years after Malthus, the sole threat to humanity's survival was to be found in weapons of its own making. And today, the power of technology to produce food is indefinitely greater than the "power" of population growth (see, e.g., Cohen 2010, 18). Holding technology constant, the skeptic will say, yields mistaken predic- 
tions about the environment, just as it has yielded mistaken predictions with regard to subsistence.

We can now close this section, with the following interim conclusion. As long as environmentalists retain their focus on future generations, they cannot prove, on our skeptic's terms, that the development of green energy is crucial. Insofar as environmentalists have reason to value such a strategic argument, they need to find alternative ways to make it. Specifically, environmentalists need a present-oriented argument focused on negative duties to respect rights, which emphasizes technological optimism. If this argument can focus on negative duties to respect present rights central to American skeptics, this would be even better. The argument to which I now turn aims to provide all of these things.

\section{AN ALTERNATIVE ARGUMENT FOR GREEN ENERGY: THE PROBLEM OF TRADE WITH PETROCRATS}

The alternative justification for green energy policies that I wish to elaborate here starts with a simple thought: negative duties, the kind of duties that our skeptic cherishes, travel in space much more easily than they travel in time. Our skeptic may devise multiple arguments for why negative duties toward noncontemporaries are neither as clear nor as forceful as negative duties toward contemporaries. But, even if negative duties are indeed diluted by temporal distance, they are not diluted by spatial distance-nor, for that matter, by "distances" of identity or citizenship. Whatever conceptual problems we may face in asserting negative duties toward noncontemporaries, we face no such difficulties in asserting negative duties toward contemporaries who are noncompatriots. There is no spatial gradient for our duties not to violate rights. As Pogge writes, “The moral reasons to refrain from drunk driving do not become much weaker when we are briefly working in India or holidaying in Indonesia. They remain strong when those one is putting in jeopardy are not neighbors or compatriots but people with a different language, culture, religion, latitude or nationality" (Pogge 2010, 212). Now, if environmentalists can identify ongoing violations of global negative duties toward contemporaries that trigger a need for affluent democracies to develop green energy, this will have strategic value in debating American skeptics on their own terms. Such strategic value will be particularly pronounced, if the relevant violations refer to rights that American skeptics themselves prioritize. I wish to suggest that there is at least one ongoing type of rights violations that fits this description: the massive-scale violations of national property rights that occur when affluent democracies allow corporations based in their territories to purchase oil controlled by dictators.
The normative argument for why such purchases should be considered violations of national property rights has become familiar over the last decade, but it is nonetheless worth repeating here. ${ }^{8}$ The argument begins from two basic premises. The first premise is that state-owned natural resources, like all state property, belong to the people as a collective agent rather than to the individuals wielding effective political power. ${ }^{9}$ The second premise is that meaningful ownership over a resource requires the ability to control the resource. Therefore, in order for their property rights over state resources to be respected, peoples as collective agents need to be able to control these resources. Accordingly, if they are to respect their people's ownership of state resources, individuals who wield effective political power, and who sell state resources in their people's name, must claim proper authorization from the people to engage in such sales. But regimes that rely on bullets rather than ballots to secure political power cannot claim the requisite authorization. Such regimes often sell state-owned natural resources without allowing their people to know about these sales; rarely, if ever, allow their people to protest natural resource sales; and never allow the people to control the resulting revenue through elected delegates. Such regimes can therefore be said to be systematically violating their people's property rights.

In turn, prospective purchasers of state-owned natural resources who know that such violations are taking place ought not transact with the regimes committing these violations. Just as individuals have a duty not to buy property that they know the vendor has illicitly seized from the real owner (person $A$ ought not buy from $B$ what she knows that $B$ has illicitly seized from the real owner $C$ ), corporations have a duty not to buy (national) natural resources that they know certain regimes have come to control in illicit ways. ${ }^{10}$

Different political philosophers elaborating this argument have offered different accounts as to which regimes should be considered violators of their peoples' property rights, and thus as illegitimate vendors of natural resources. I believe the most convincing account is one that sees only and all dictatorships as violators of their people's property rights. For the purposes of this account, "dictatorships" are defined as

8. Pogge (2001); Wenar (2008, 2011). See also Nili (2011b, 2011c).

9. Wenar $(2008,10)$ might be somewhat oversimplifying, but he nonetheless captures an important point when noting that "the idea that the natural resources of a country belong to the people of that country is so intuitive that most will need no more proof than its statement." Barring anarchist views, I believe this idea can be defended from the perspective of most if not all familiar theories of property rights, including even many cosmopolitan theories. But showing this will take me too far afield.

10. For an emphasis on this analogy, see Pogge $(2005,737)$ and Wenar (2008, 17-19). 
regimes that clearly lack free and fair elections and a rule of law binding upon those wielding effective political power. ${ }^{11}$ In the absence of free and fair elections, dictators cannot claim proper authorization from the people to manage the people's natural resources. In the absence of a rule of law, dictators cannot be formally and legally accountable to the people as the owner of national property-there is no mechanism to sanction dictators who abuse their control over this property. ${ }^{12}$

It is important, for reasons that will become clear shortly, to further specify the scope of this argument - the kinds of regimes whose natural resource exports ought to be seen as illegitimate. On the one hand, orienting the argument toward all and only dictatorships means putting outside its scope those regimes that can be considered flawed democracies: regimes that clearly take free and fair elections and the rule of law seriously, even if imperfectly, should be considered legitimate vendors of their people's natural resources. ${ }^{13}$ On the other hand, the category of "only and all dictatorships" includes within the argument's scope both dictatorships that deprive their peoples of almost all natural resource revenues and those dictatorships that distribute much of this revenue to the people in the form of public spending. Both "distributive" and "depriving" dictatorships are to be considered violators of their people's property rights, and their natural resource exports should accordingly be deemed illegitimate. ${ }^{14}$

Once the argument extends to cover distributive dictatorships as well depriving ones, it can make an extremely significant-even if indirect-contribution to environmentalists' policy agenda. This is because, once applied to all dic-

11. For the intimate connection between free and fair elections and rule of law, see Maravall and Przeworski (2003).

12. For an emphasis on how control of state property requires democratic procedures and cannot be satisfied even by "decent hierarchies," see Nili (2013a, 488-92).

13. Turkey, at least during decades of explicit military involvement in politics accompanying elections, can be seen as one example of a flawed democracy. More importantly, in terms of oil-rich countries, Venezuela, at least after Chavez, may be considered another example of a flawed democracy. There are obviously different ways of distinguishing among regime types, and I recognize that some political scientists might be skeptical of a sharp distinction between democracy and dictatorship. Yet we can put such potential disagreements aside here, insofar as most if not all of the regimes I will discuss (especially Russia and Saudi Arabia) will be ones where the label "dictatorship" can be applied without much controversy. For a general discussion of extensions to the democracy dictatorship distinction, see Cheibub, Gandhi, and Vreeland (2010).

14. At least as a matter of principle. The principle can be outweighed where is a credible threat that ending customary trade will yield absolute deprivation, but I am assuming that in affluent dictatorships such as Saudi Arabia, and even in countries such as Russia, this threat is extremely limited. For extended background on this assumption, see Nili, "A Theory of Global Injustice” (2015). tatorships, the argument renders illegitimate a crucial portion of affluent democracies' sizeable oil imports. And this fact, in turn, connects in two ways to green policies.

First, there is the theoretical possibility that affluent democracies will pursue policies to reduce their energy consumption, so as to offset the "lost" oil supplies that they will now prohibit their corporations from purchasing. Such a scenario will obviously be extremely positive from an environmentalist perspective (see Wenar 2008, 30). But given just how dramatic the reduction in energy consumption would have to be, and given the repercussions this would have for economic activity, our skeptic, attached as he is to continuous economic growth and prosperity, is much more likely to prefer the second option: prioritizing the development of green alternatives to oil that will make it possible for affluent democracies to reform customary oil trade while retaining current levels of energy consumption. ${ }^{15}$

I will spend the remainder of this article on further developing this latter option by anticipating likely objections. Before doing so, however, I wish to reiterate how the connection between green energy and the duty to reform customary oil trade is strategically useful for environmentalists who wish to justify the prioritization of green energy development even to moderate environmental skeptics.

These strategic green advantages arise, first and foremost, from the argument's emphasis on a negative duty to respect property rights. Admittedly, the property rights invoked here refer to a people's ownership over state property rather than to individual property. But, notwithstanding possible impressions to the contrary, there is no reason why this should matter in the context of our discussion. Indeed, to explicitly return the focus to the United States, as a matter of historical fact, it is clear that some of its most anti-environmentalist leaders, including those who have sought to minimize the role of state ownership and regulation in the economy, have clearly taken seriously the property rights invoked here. As Leif Wenar notes, when the Reagan administration, for instance, sold to Shell the rights to oil deposits off the coasts of Louisiana and Florida, these deposits may have become private property, but the revenue from the sale clearly belonged to the American people rather than to the president personally: "one can imagine the response had President Reagan secretly sold this oil to Shell, then put the profits from these sales into his private bank account and ordered the FBI to detect and squash any dissent" (Wenar 2008, 10). Similarly, when President George W. Bush, for example, discussed Iraqi

15. It should also be added that any elected government that imposed such a dramatic reduction of energy consumption, with the attendant economic consequences, can expect to be voted out of office. 
oil after the overthrow of Saddam Hussein, there was no mention of any private appropriation of this oil preceding its ownership by the people. "The oil," the president declared, "belongs to the Iraqi people. It's their asset."16

The other strategic advantage of arguing from reform of customary oil trade to green energy is avoiding the marking of environmentalists as technophobes who underestimate technology's ability to better human life and solve societal problems. In highlighting this point, I do not mean to portray environmentalists in general as having an antitechnological orientation. I only wish to emphasize the contrast between an environmentalist position that is forced-even if only through external criticism - to identify itself with bleak predictions holding technology constant (as noted above), and on the other hand a position that places environmentalists as believers in what technology can achieve-specifically, in technology's ability to devise green solutions that will disentangle affluent democracies from their oil dependence.

\section{FROM DICTATORIAL OIL TO GREEN ENERGY?}

Let us now turn to possible objections. The first possible objection that I wish to address comes from those who might be suspicious of the empirical basis of my argument. Some may think that affluent democracies' dependency on oil controlled by dictators is not significant to such a degree that a decision to stop recognizing dictators as legitimate vendors of their peoples' oil will necessitate wide-scale shifts in energy policy.

This objection is inaccurate. To see why, we can start with the example of the United States. In 2012, for instance, according to the US Energy Information Administration (EIA), the distributive dictatorships of the Persian Gulf alone-Bahrain, Kuwait, Qatar, United Arab Emirates, and, most importantly, Saudi Arabia-accounted together for more than a quarter of US oil imports (which in turn accounted for two fifths of US oil consumption). Putin's dictatorship in Russia provided another five percent of US oil imports. We thus reach more than thirty percent of US oil imports even before examining many other dictatorships that, while individually accounting for only a fraction of US oil imports in a given year, ultimately add up. The EIA reported that Angola, for example, accounted for about two and a half percent of US oil imports; Cameroon, Chad, Congo, Equatorial Guinea, Ga-

16. "President's Statement to the Press," June 12, 2006, http://www .gpogov/fdsys/pkg/PPP-2006-book1/html/PPP-2006-book1-doc-pg1117.htm. Quoted also in Wenar $(2008,10)$. A more abstract way of making the point would be to say that the issue of state property illustrates the key differences between Lockean political philosophy and libertarian-anarchist philosophy. For a similar emphasis on the distinction between Lockean minimal government and libertarian no-government, see Zuckert (2002, chap. 13). bon, Azerbaijan, and Kazakhstan combined for about two percent. The dictatorships mentioned in this paragraph alone thus made up more than a third of US oil imports for 2012about twelve hundred million oil barrels. ${ }^{17}$

The situation of the European Union (EU) in the same year was even worse. Importing roughly the same amount of oil as the United States, EU member states imported more than thirty percent of their oil from Russia; more than nine percent from Saudi Arabia; almost nine percent from Azerbaijan and Kazakhstan; and about six percent from Algeria, Cameroon, Congo, Angola, and Gabon. These dictatorships accounted for more than half of the EU's oil imports for 2012 - more than two billion oil barrels. Even before we get to democracies other than the United States and the EU countries, we can see that democracies remain heavily dependent on oil controlled by dictators. ${ }^{18}$

Examining these figures, some critics might raise the following, normative objection. The argument's practical impact hinges on the claim that democracies ought to boycott the natural resource exports of distributive dictatorships, most importantly, Saudi Arabia and Russia. However, the normative grounding of such a boycott is not strong enough when it comes to distributive dictatorships. It makes sense to boycott the natural resource exports of a petrocrat who uses the state's oil revenue to buy multiple personal jets while raw sewage runs through the capital's streets and the majority of the people are chronically malnourished (as in Equatorial Guinea; Wenar $2008,6-7)$. Yet violations of national property rights are far less alarming in a dictatorship that distributes benefits from oil revenues to its people. As long as significant benefits are flowing to the population, the mere fact that the regime is depriving its people of control over national oil is not sufficiently disturbing to warrant the dramatic step of boycotting the regime's natural resource exports.

However intuitive it may seem, this objection is no more successful than its predecessor, for at least four reasons. First, in focusing so strongly on the benefits from national property, the objection unduly marginalizes the independent normative weight of owners' ability to control their property. ${ }^{19}$ If, for instance, the mafia violently seizes effective control of a business without the valid consent of its owner, the possi-

17. See the EIA's "U.S. Imports by Country of Origin," www.eia.gov /dnav/pet/pet_move_impcus_a2_nus_ep00_im0_mbbl_a.htm, and "How Dependent Are We on Foreign Oil?,” http://www.eia.gov/energy_in_brief /article/foreign_oil_dependence.cfm.

18. See European Commission, "Monthly and Cumulated Crude Oil Imports (volumes and prices) by EU and Non EU Country," http://ec .europa.eu/energy/observatory/oil/import_export_en.htm (file titled "eu-coi -from-extra-eu-2012-01-12").

19. This point follows Nili (2011a, 103-24). 
bility that the mafia also directs revenues from the business to the owner does not change its fundamental violation of the owner's property rights. More generally, one cannot take the very idea of property seriously, unless one takes seriously agents' right to control their property, independently of where the benefits that might be derived from the property go.

Second, related, in marginalizing the independent moral significance of owners' ability to control their property, the objection adopts a paternalistic stance that is not only alien to the normal understanding of property in general but is also, more specifically, alien to the antipaternalist normative framework we are presupposing here. The objection amounts to the claim that depriving agents of control over their property is not much of a moral problem as long as this is done in ways that might be commensurate with their interests. But this claim is diametrically opposed to the way in which antipaternalist views - in the United States in particular - often understand the significance and grounds of property rights. In the antipaternalist picture, the deep moral significance of property rights derives from the fact that they allocate to agents a crucial sphere of freedom to make their own choices, even when agents' choices might come at the expense of their own interests. This antipaternalism is evident in calls - familiar especially from the right wing of American politics - to allow individuals the "freedom to fail" with the choices they make regarding their property. And the same antipaternalism is essential to the familiar opposition to various government measures that limit agents' control over their property "for their own good." From an antipaternalist perspective in particular, then, it makes little sense to focus on benefits from property and to marginalize the significance of agents' ability to control their property.

Third, again related, if all that mattered with regard to a people's property was that the people enjoyed enough of the revenue from this property, regardless of who controlled it, then it is unclear how we could explain our intuitive objection to paternalistic colonial control of national property. ${ }^{20}$ After all, colonial masters could be just as "benign" as local dictators have been in distributing to the ruled material benefits from the resources they seized. But hardly anyone would accept such distribution as permitting the violent colonial seizing of the resources of other peoples. Why should the case be different when the perpetrators are not colonial foreigners but rather local presidents, juntas, or royals?

Finally, the objection is also problematic in suggesting an overly rosy picture of how distributive dictatorships manage the benefits from their people's oil. There are strong rea-

20. On this point, I follow Wenar (forthcoming). sons, both theoretical and empirical, to think that even dictatorships that channel a relatively stable and significant portion of the country's oil revenue to advance their population's needs systematically embezzle the remainder. Not constrained by reliable institutional mechanisms of accountability and transparency, and aided by the profound secrecy of the oil industry, ${ }^{21}$ ruling elites, even in distributive dictatorships, inevitably abuse the people's oil revenue for private ends, on a far-from-trivial scale. This charge applies, among others, to Saudi Arabia, where complaints are now explicit that members of the ruling clan treat the country's vast oil riches as "spoils" to be shared among themselves, ${ }^{22}$ and to Russia, where strongman Vladimir Putin is believed to have amassed, in large part out of embezzled oil revenues that belong to his people, a personal fortune exceeding forty billion dollars (Harding 2007, 2011).

I should emphasize that in making these points, I do not mean to deny that the violations of national property rights, and the negative duty to end the complicity of liberal democracies in these violations, are more urgent in depriving dictatorships than in distributive dictatorships. ${ }^{23}$ But the fact that violations of national property rights are especially disturbing in the former case does not mean that the latter is negligible.

Let us move then to the next objection. According to this objection, my strategic argument is unreliable, because it can only have force as long as resource-rich dictatorships do not democratize. If they did, there would be no problem with continuing to consume their oil, and so the argument would produce no new grounds for developing green alternatives to oil.

There are two related reasons why this objection fails. First, it portrays the existence of dictatorships in oil-rich countries as accidental (maybe even ephemeral). But this portrayal is misleading, as the social science debate on the "oil curse" shows. Despite various disagreements, both social scientists who believe that oil abundance causes political and economic maladies, and their critics who insist that

21. Emphasized, for instance, in Ross (2012).

22. See "The Long Day Closes," Economist, June 23, 2012, http:// www.economist.com/node/21557327.

23. Nor do I mean to deny that trade with distributive dictatorships can trigger distinct questions. Thus, for instance, we can ask whether even peoples who do see themselves as victims of distributive dictatorships might consent to democracies continuing trade with these dictatorships out of fear of a boycott's economic consequences. I do not have the space to pursue this intricate question here. I will, however, note my belief that it ultimately does not remove the moral duty to reform customary trade, partly because of problems of invalid consent and partly because of reasons of integrity that liberal democracies have against continued entanglement in dictators' natural resource dealings. On these considerations, see Nili (forthcoming a, forthcoming b). 
oil endowments have no independent causal force, agree on the following key point: once a situation exists where a dictatorship controls abundant oil reserves, there is a clear danger of a vicious cycle, with the regime perpetuating its hold on power, through its control of oil wealth, at the population's expense, countered not by democratization, but by civil wars or coups to capture the oil wealth (see, e.g., Acemoglu and Robinson 2012; Haber and Menaldo 2011; Morrison 2009). This cycle means that as long as customary trade continues, the prospects for democratization in many oil-rich dictatorships are at best limited.

Second, prohibiting oil corporations from transacting with petrocrats might itself be necessary for breaking this vicious cycle - for depriving petrocrats of the oil wealth with which they fund their rule and for taking away a key incentive for coups and civil wars. But if this prohibition, in turn, realistically depends on the availability of green alternatives to oil (assuming existing levels of energy demand), then the objection gets the sequence of events wrong. The sequence of changes does not begin with petrocrats democratizing, thus taking away the need to develop green alternatives to the oil they control. Rather, the sequence begins with the development of green alternatives that will make it possible to reform transactions with petrocrats, a reform that might itself be a necessary condition for democratization. ${ }^{24}$

The final objection I wish to anticipate takes aim at a different part of my strategic argument. According to this objection, my argument hinges on a false setup of the relevant choice situation facing affluent democracies (and the United States in particular). Rather than developing green alternatives to oil controlled by dictators, both democratic governments and markets can instead turn to other alternatives to conventional oil that will only increase environmental problems including the exploration of domestic oil deposits in environmentally sensitive areas or additional governmental support

24. Saying that prohibiting oil purchases from petrocrats might be a necessary condition for their democratization is of course different from saying that this would be a sufficient condition. And it is also different from saying that the duty to enact such a prohibition is contingent on whether a prohibition will trigger democratization. One can argue that Western oil corporations ought to stop their complicity in Putin's theft of the Russian people's oil wealth, for example, independently of whether such a stop will facilitate democratization of the Russian regime. More generally, one could argue that just as colonial powers had a duty to end colonial rule, independently of the uncertainty as to how decolonization would affect their victims, and just as liberal democracies had a moral duty to divest from apartheid independently of the uncertainty as to divestment's effects, so there ought to be, at minimum, a very strong presumption in favor of divestment when it comes to the (essentially neo-colonial) customary trade in natural resources. For similar remarks see Nili (2013b, forthcoming a); see also Marinov and Nili (forthcoming); and Nili (forthcoming c). for new technologies such as hydraulic fracturing to recover shale gas and oil (also known as "tight oil").

This objection ignores some significant issues. For one thing, the objection assumes (however implicitly) that the genuine availability of anti-green alternatives to conventional oil is obvious and straightforward. But it is not. Many scientists continue to dispute whether anti-green alternatives such as tight oil have real potential to "do the work" that conventional oil does now, in large part because of their extremely low ratio of energy returned on energy invested (EROI). ${ }^{25}$ Thus, for example, the editors of a December 2013 special issue on "The Future of Oil Supply," published by the physical sciences journal of the Philosophical Transactions of the Royal Society, summarized the issue as providing "a sobering picture of the challenges ahead":

Most authors accept that conventional oil resources are at an advanced stage of depletion and that liquid fuels will become more expensive and increasingly scarce. The tight oil "revolution" has provided some shortterm relief, but seems unlikely to make a significant difference in the longer term. Even with a more sanguine view of global supply prospects, the large scale, capital intensity, long lead times and constrained potential of the various mitigation options point to the need for a coordinated response ... there is a growing consensus that the era of cheap oil has passed and that we are entering a new and very different phase. (Miller and Sorrell 2014, 2, 24; italics mine)

Alongside the basic scientific issue, there is also a deeper problem with the objection, which requires more elaboration. The objection in effect assumes that there needs to be a special reason for the skeptic to prioritize green over "antigreen" energy. But this is not the case. Since he concedes the existence of environmental threats, and since green energy, by definition, would mitigate these threats, the skeptic in fact concedes that special reasons have to be given in order to prioritize anti-green energy. The skeptic simply believes that he can indeed offer such reasons, which outweigh the environmental benefits of green energy. What we need to ask, then, is what these reasons are, and whether they remain operative once the implications of reforming oil trade are taken into account. If they do not, then - as we will see-the skeptic would have to prioritize the development of green energy even when compared to all anti-green options.

25. Even accounting for new technologies to recover tight oil, its EROI stands at 1.5:1, vastly inferior to conventional oil, standing at 20:1. See Cleveland and O'Connor (2011). 
I believe there are two claims that the skeptic must invoke to excuse continued reliance on anti-green energyand specifically on oil-under present circumstances. First, a path-dependency claim: "Certainly," the skeptic will admit, "green energy would have to be given priority if we were designing our energy policies ex nihilo, with little or no costs already invested in specific choices. However, our present condition is different. Rather than designing energy policies on a blank slate, our choices are already significantly affected by the past choices that have structured economies, regulation and infrastructure around oil. The sheer fact that oil has been the dominant energy basis of industrialized nations for almost a century means that a fundamental shift to any other source of energy, simply in virtue of being a fundamental shift, would require massive resources and adjustments from the private sector, from government, and from ordinary citizens. Everyone will have to endure tremendous set-up costs, extensive uncertainties, massive coordination issues, and prolonged learning processes."

Second, related, the skeptic will invoke a simple price claim: "As long as serious environmental threats are not yet imminent," the skeptic will say, "there is not enough reason to undertake such difficult shifts when the price of oil-notwithstanding its volatility-generally remains low enough. To be sure, at some point we will have to start shifting to other forms of energy, simply because oil is finite. But that point is still quite far. At least in the medium run, the fact that oil remains cheap makes it sensible to accept the inertia of oil reliance. Until that fact changes, we have more urgent problems to prioritize."26

Now consider how these two claims would be affected if democracies prohibited their corporations from purchasing oil held by dictators, while seeking to retain the same level of energy consumption. Start with the price claim. While the appeal to the cheap price of oil may obtain in the existing energy market, it is very unlikely to obtain in a market in which democracies prohibited their corporations from purchasing dictators' oil, but retained current energy demand. Given that, as we have seen, democratic oil imports from dictators make up a sizeable portion of global oil trade, if democratic importers will be committed to stop buying oil from dictators while keeping current levels of energy demand, this would produce a dramatic - and, as opposed to what is currently the case, enduring rise - in the price of "legitimate" oil. ${ }^{27}$

26. Consider Bjørn Lomborg again: "When we are told that something is a problem we need to ask how important it is in relation to other problems. We are forced to constantly prioritize our resources, and there will always be good projects we have to reject" (Lomborg 2001, 9).

27. Consider, for instance, how the removal of Saudi and Russian oil alone would impact the price of Norwegian oil.
In turn, this rise will also nullify the skeptic's pathdependency claim concerning the significant costs of energy shifts. The reason is that once the cost of oil imports becomes prohibitive, such shifts would be necessary in any case. Since the many affluent democracies that rely on foreign oil imports would have to seriously curtail these imports, they will have no choice but to make fundamental shifts in their energy base. ${ }^{28}$ Thus, fear of the multiple kinds of costs associated with shifts as such would become irrelevant.

By triggering a steep increase in oil prices, a democratic prohibition on oil purchases from dictators therefore takes away both of the skeptic's excuses for not prioritizing the development of green energy. Once the path-dependency and the price consideration are no longer operative, the skeptic cannot explain why the development of green energy should not become a key priority, even when compared to anti-green alternatives other than oil.

This claim can also be made in more specific form, as follows. By necessitating a transformation of energy policy, reform of customary oil trade turns on its head the skeptic's fear of the costs of energy policy shifts. Instead of justifying avoidance of green energy development, the emphasis on the costs of policy shifts becomes an argument for prioritizing the development of green energy. The reason is this. If policy makers are compelled to undertake an energy policy shift, and if they are sensitive to the aforementioned costs associated with any shift, they are likely to prioritize those present transitions that would avoid or reduce the need for additional transitions in the future. Since green energy, by definition, does not entail long-term threats that would necessitate additional changes later on, it has a crucial advantage over anti-green forms of energy that would eventually necessitate such changes, simply because of the long-term dangers that they entail.

To these arguments regarding the impact of exogenous shocks on anti-green energy inertia, one can add three briefer points. First, agitation over projects that deepen anti-green energy inertia-from intense debates over the US-Canada pipeline to ongoing disputes over fracking - is evidence of already-existing widespread suspicion of further steps down anti-environmental routes. But to take such steps as a committed national policy - to actively (re)choose the path of anti-environmental energy, as distinct from merely following the same path out of inertia - could very well trigger public disapproval of a much deeper sort. Indeed, public opinion research shows that even among those segments who see the

28. Thus, for example, according to the US Energy Information Administration, in 2012, "about $57 \%$ of the crude oil processed in US refineries was imported." See "How Dependent Is the United States on Foreign Oil?," http://www.eia.gov/tools/faqs/faq.cfm?id $=32 \& t=6$. 
environmental movement as overly alarmed, there is often a basic recognition of environmental problems and willingness to support at least some public policies that will address those problems (Smith and Leiserowitz 2013), including support for long-term increase in the use of green energy, support for longterm decrease in the use of fossil fuels, and opposition to subsidization of fossil-fuel industries. ${ }^{29}$ A massive spur in the development of anti-green energy, however, would go in exactly the opposite direction.

A second, and very much related, point, concerns oil market dynamics. If one is inclined to think that anti-green energy can replace the oil that democracies import from dictatorships, this is probably because one believes that the oil market will itself "solve the problem," as alternatives to conventional oil become more easily available with time. But this belief is confounded not only by the scientific issues flagged above. It is also confounded by the fact that the oil market is actually more complicated. There are actors who have a great deal to lose from the rise of nonconventional oil-most importantly, the dictatorships that depend on conventional oil exports. These dictatorships are likely to do anything in their power to strangle the nonconventional oil industry in the cradle, most immediately, by letting the oil price fall—as Saudi Arabia has - in order to push many producers of nonconventional oil out of business. ${ }^{30}$ This point suggests that in order to protect the nascent nonconventional oil industry from external pressure, democratic governments, including the US government, might very well have to provide extensive subsidies to these industries over an extensive period of time. ${ }^{31}$ Such subsidies, however, will not only conflict with the policy preferences of a significant portion of the American public (as I just noted) and, more generally, conflict with public suspicion of a policy recommitting to anti-green energy. Even more fundamentally, such subsidies trigger a basic question: if the effort to develop alternatives to oil controlled by

29. In this context, the Six Americas project is once again instructive. The project's September 2012 survey found that "majorities of all Six Americas say the United States should increase its use of renewable energy"; that "In five of the six segments, larger proportions prefer to reduce, rather than increase fossil fuel use"; and that "in every segment except the Dismissive, half or more favor the elimination of subsidies to the fossil fuel industry, and oppose the elimination of subsidies to renewable energy companies." See Leiserowitz et al. $(2013,2)$.

30. See "Sheikhs v Shale," Economist, December 6, 2014, http://www.econo mist.com/news/leaders/21635472-economics-oil-have-changed-some-businesses -will-go-bust-market-will-be.

31. This is particularly the case given that Saudi Arabia has savings of $\$ 900$ billion, and so, as Economist also emphasizes, "can afford self-denial" over a substantial period of time. See "Making the Best of a Low Price: What Is the Oil Cartel Up To?," Economist, December 6, 2014, http://www.economist.com /news/finance-and-economics/21635510-what-oil-cartel-up-making-best-low-price. dictators is going to involve significant economic costs in any case, why not direct this effort toward the path that has the best prospects of long-term sustainability?

The final point I wish to make is again related. Public reluctance about a dramatic buildup of anti-green energy might be particularly intense given that such buildup will require internalizing much of the environmental cost of anti-green energy that affluent democracies have so far managed to "send" elsewhere. Affluent countries have frequently been trying (self-deceivingly?) to keep environmental threats at a distance by, for instance, sending their nuclear waste to be buried in the global south. A prohibition on purchasing oil from dictators will, quite literally, bring home the environmental costs of anti-green energy. If much more of this energy would have to be produced domestically, this wouldamong other things - greatly increase the risk to air and water quality in democratic countries, as well as the risk of environmental disasters such as the Exxon Valdez or the BP oil spill recurring in affluent democracies rather than in "distant" poor countries. Such increased and highly visible risks are unlikely to be ignored by the general public and by governments accountable to the public. Therefore, the more affluent democracies need to sacrifice their own environment for economic goals rather than the environment of the poor, the more likely they are to avoid anti-environmental policies. This is perhaps one reason why even President George W. Bush, for example, who led a highly anti-environmentalist administration, declared that oil from foreign authoritarians has to be replaced not with more domestic oil but rather with green energy - exclaiming in his 2006 State of the Union Address that "America is addicted to oil, which is often imported from unstable parts of the world. The best way to break this addiction is through technology ... cleaner, cheaper, and more reliable alternative energy sources." ${ }^{32}$

\section{CONCLUSION}

My aim in this article was to construct a strategic argument for green energy that, being focused on negative duties to respect the property rights of present people(s) over their oil, can appeal, especially in the American context, even to those who are skeptical of climate change. I wish to reiterate that this strategic argument is meant to supplement, rather than replace, familiar environmentalist arguments for green policies. Nothing in what I have said here is meant to suggest that environmentalists should forsake their principled opposition to many (normative and empirical) claims made by environmental skeptics. My argument is intended as an ad-

32. See the 2006 US State of the Union transcript, available at http:// www.cbsnews.com/2100-250_162-1264706.html. 
ditional, distinctive way to increase support for a policy that environmentalists themselves deem vital.

\section{ACKNOWLEDGMENTS}

Several people have provided extraordinarily helpful advice and criticism on the themes of this article. For conversations and comments, thanks to Anna auf dem Brinke, Alyssa Battistoni, David Brent, Simon Caney, David Ewert, Mary McGrath, Burke Hendrix, Jeff Isaac, Devin Judge-Lord, Pius Kruetli, Melissa Lane, Tony Leiserowitz, Lukas Meyer, Rachel Payne, Thomas Pogge, Ian Shapiro, Leif Wenar, and Michael Zuckert. Thanks also to two anonymous reviewers, and to Lisa Ellis, for very generous feedback.

\section{REFERENCES}

Acemoglu, Daron, and James Robinson. 2012. Why Nations Fail: The Origins of Power, Prosperity and Poverty. New York: Random House.

Cheibub, José A., Jennifer Gandhi, and James R. Vreeland. 2010. "Democracy and Dictatorship Revisited.” Public Choice 143:67-101.

Cleveland, Cutler, and Peter O'Connor. 2011. "Energy Return on Investment (EROI) of Oil Shale." Sustainability 3 (11): 2307-22.

Cohen, Joshua. 2010. "Philosophy, Social Science, Global Poverty." In Alison Jaggar, ed., Thomas Pogge and His Critics. Cambridge: Polity, 18-45.

de-Shalit, Avner. 2000. The Environment: Between Theory and Practice. Oxford: Oxford University Press.

Dunlap, Riley, C. Xiao, and A. M. McCright. 2001. "Politics and Environment in America: Partisan and Ideological Cleavages in Public Support for Environmentalism." Environmental Politics 10:23-48.

Elliot, Robert. 1989. “The Rights of Future People." Lournal of Applied Philosophy 6:159-69.

Feinberg, Joel. 1981. "The Rights of Animals and Unborn Generations.” In Ernest Partridge, ed., Responsibilities to Future Generations: Environmental Ethics. New York: Prometheus.

Florini, Ann. 2012. “The Peculiar Politics of Energy.” Ethics and International Affairs 26 (3): 293-309.

Gosseries, Alex. 2008. “On Future Generations' Future Rights.” Lournal of Political Philosophy 16 (4): 446-74.

Haber, Stephen, and Victor Menaldo. 2011. "Do Natural Resources Fuel Authoritarianism? A Reappraisal of the Resource Curse." American Political Science Review 105 (1): 1-26.

Harding, Luke. 2007. "Putin, the Kremlin Power Struggle and the \$40bn Fortune," Guardian, December 21.

Harding, Luke. 2011. Mafia State. London: Guardian.

Jacques, Peter, Riley Dunlap, and Mark Freeman. 2008. "The Organisation of Denial: Conservative Think Tanks and Environmental Scepticism.” Environmental Politics 17 (3): 349-85.

Layzer, Judith. 2012. Open for Business. Cambridge, MA: MIT Press.

Leiserowitz, Anthony, Edward Maibach, Connie Roser-Renouf, Geoff Feinberg, and Peter Howe. 2013. Global Warming's Six Americas, September 2012. New Haven, CT: Yale Project on Climate Change Communication.

Leiserowitz, Anthony, and Nicholas Smith. 2012. "The Rise of Global Warming Skepticism: Exploring Affective Image Associations.” Risk Analvsis 32 (6): 1021-32.

Lomborg, Bjørn. 2001. The Skeptical Environmentalist: Measuring the Real State of the World. New York: Cambridge University Press.

Macklin, Ruth. 1981. "Can Future Generations Correctly Be Said to Have Rights?” In Ernest Partridge, ed., Responsibilities to Future Generations: Environmental Ethics. New York: Prometheus.
Malthus, Thomas. (1798) 2008. An Essay on the Principle of Population. Oxford: Oxford University Press.

Maria Maravall, Jose, and Adam Przeworski, eds. 2003. Democracy and the Rule of Law. Cambridge: Cambridge University Press.

Marinov, Nikolay, and Shmuel Nili. Forthcoming. "Sanctions and Democracy." International Interactions.

Meyer, Lukas. 1997. "More than They Have a Right to: Future People and Our Future Oriented Projects.” In Nick Fotion and Jan C. Heller, eds., Contingent Future Persons: On the Ethics of Deciding Who Will Live, or Not, in the Future. London: Kluwer.

Miller, Richard G., and Steven R. Sorrell. 2014. "Introduction: The Future of Oil Supply." Philosophical Transactions of the Royal Society A: Mathematical, Physical and Engineering Sciences 372:1-28.

Morrison, Kevin. 2009. "Oil, Nontax Revenue, and the Redistributional Foundations of Regime Stability.” International Organization 63 (1): 107-38.

Nili, Shmuel. 2011a. "Conceptualizing the Curse: Two Views on Our Responsibility for the Resource Curse." Ethics and Global Politics 4 (2): 103-24.

Nili, Shmuel. 2011b. "Democratic Disengagement: Towards Rousseauian Global Reform.” International Theory 3 (3): 355-89.

Nili, Shmuel. 2011c. "Our Problem of Global Justice." Social Theory and Practice 37 (4): 629-53.

Nili, Shmuel. 2013a. "Rawlzickian Global Politics." $\underline{\text { ournal of Political Philos- }}$ ophy 21 (4): 473-95.

Nili, Shmuel. 2013b. "Rigorist Cosmopolitanism: A Kantian Alternative to Pogge." Politics, Philosophy and Economics 12 (3): 260-87.

Nili, Shmuel. 2015 "A Theory of Global Injustice." Unpublished manuscript.

Nili, Shmuel. Forthcoming a. "Customary Trade and the Complications of Consent." Journal of Applied Philosophy.

Nili, Shmuel. Forthcoming b. "Liberal Integrity and Foreign Entanglement." American Political Science Review.

Nili, Shmuel. Forthcoming c. "Liberal Global Justice and Social Science." Review of International Studies.

Oreskes, Naomi, and Erik Conway. 2010. Merchants of Doubt. London: Bloomsbury Press.

Pogge, Thomas. 1989. Realizing Rawls. Ithaca, NY: Cornell University Press.

Pogge, Thomas. 2001. "Achieving Democracy." Ethics and International Affairs 15 (1): 3-23.

Pogge, Thomas. 2005. "Recognized and Violated by International Law: The Human Rights of the Global Poor." Leiden Journal of International Law 18:717-45.

Pogge, Thomas. 2010. "Reply to Critics." In Alison M. Jaggar, Pogge and His Critics. Cambridge: Polity, 175-250.

Rawls, John. 1999. A Theory of Justice. Rev. ed. Cambridge, MA: Harvard University Press.

Roser-Renouf, Connie, Edward Maibach, Anthony Leiserowitz, Geoff Feinberg, Seth Rosenthal, and Jennifer Kreslake. 2015. Global Warming's Six Americas, October 2014. New Haven, CT: Yale Project on Climate Change Communication.

Ross, Michael. 2012. The Oil Curse. Princeton, NJ: Princeton University Press. Schlosberg, David. 2013. "Theorising Environmental Justice: The Expanding Sphere of a Discourse.” Environmental Politics 22 (1): 37-55.

Smith, Nicholas, and Anthony Leiserowitz. 2013. "American Evangelicals and Global Warming." Global Environmental Change 23:1009-17.

Wenar, Leif. 2008. "Property Rights and the Resource Curse." Philosophy and Public Affairs 36 (1): 2-32.

Wenar, Leif. 2011. "Clean Trade in Natural Resources." Ethics and International Affairs 25 (1): 27-39.

Wenar, Leif. Forthcoming. Clean Trade. Oxford: Oxford University Press. Zuckert, Michael. 2002. Launching Liberalism: On Lockean Political Philosophy. Lawrence: Kansas University Press. 